\title{
PERTUMBUHAN DAN PRODUKSI STEK BATANG Asystasia gangetica PADA UMUR YANG BERBEDA
}

\author{
N. R. Kumalasari, L. Abdullah, L. Khotijah, Indriani, F. Janato, dan N IIman \\ Departemen Ilmu Nutrisi dan Teknologi Pakan, Fakultas Peternakan, Institut Pertanian Bogor \\ Corresponding author: nurrkumala@gmail.com
}

\begin{abstract}
ABSTRAK
Salah satu cara reproduksi tumbuhan Asystasia gangetica (L.) T. Anderson adalah menggunakan reproduksi vegetatif melalui stek. Tujuan penelitian ini adalah untuk mengevaluasi pengaruh perbedaan umur terhadap pertumbuhan dan produksi stek $A$. gangetica. Penelitian dilakukan dengan rancangan acak lengkap 3 perlakuan umur panen (50, 70 dan 90 hari) dengan 24 kali ulangan. Parameter yang diamati adalah tinggi tanaman, jumlah ranting, berat batang, jumlah stek dan diameter stek pada saat panen. Data dianalisis dengan ANOVA dan uji lanjut LSD menggunakan software Ri386 versi 3.3.2. Hasil penelitian menunjukkan bahwa pertumbuhan tinggi tanaman $A$. gangetica cenderung membentuk pola sigmoid berupa polynomial berderajat tiga. Berdasarkan penelitian ini, tanaman berumur 90 hari memiliki tinggi $(128,1 \pm 12,3)$ dan berat batang terbaik $(156,7 \pm 18,6)$ serta menghasilkan jumlah stek yang terbanyak $(17,1 \pm 4,25)$ dan diameter stek terbesar $(4,3 \pm 0,7)$. Produksi stek $A$. gangetica berasal dari ranting primer dan sekunder.
\end{abstract}

Kata kunci: Asystasia gangetica, pertumbuhan, produksi stek, umur panen

\section{PENDAHULUAN}

Asystasia gangetica (L.) T. Anderson merupakan gulma pada lahan pertanian dan perkebunan namun telah digunakan sebagai pakan ternak di beberapa wilayah. A. gangetica memiliki kandungan protein kasar sebesar 19,3\% (Adigun et al., 2014) hingga 33\% tergantung pada bagian tumbuhan yang dimanfaatkan (Putra, 2018). Pemanfaatan A. gangetica sebagai pakan ternak ruminansia kecil sudah cukup banyak sebagai bagian dari pemangkasan gulma lahan pertanian atau perkebunan.

Pemanfaatan A. gangetica secara komersial dalam jangka panjang sebagai pakan ternak memerlukan bahan tanam yang tersedia secara kontinyu dan terjaga kualitasnya. Bahan tanam A. gangetica terdiri dari biji (generatif) dan stek (vegetatif). Perkembangbiakan A. gangetica secara generatif masih memiliki daya kecambah sekitar 71\% (Kumalasari et al., 2018). Di sisi lain, perkembangbiakan vegetatif memiliki beberapa keuntungan yaitu mudah dalam pemeliharaan, pengadaan seleksi, diperoleh tanaman baru dalam jumlah yang cukup banyak dengan induk yang terbatas, biaya lebih murah, penggunaan lahan pembibitan dapat di lahan sempit, dalam pelaksanaannya lebih cepat dan sederhana.

Pertumbuhan tanaman pakan memiliki pola khas untuk setiap tanaman yang dapat dilihat dari karakter struktur dan morfogenetik tanaman tersebut (Rodrigues et al., 2011). Pertumbuhan batang tanaman berhubungan dengan produksi cabang dan ranting yang akan berkompetisi untuk mendapatkan sinar matahari (Prusinkiewicz, 1998). Batang akan berpengaruh pada jumlah stek dan panjang yang dihasilkan serta kemampuan untuk tumbuh tanaman (Clarizky et al., 2015). Tujuan penelitian ini adalah untuk mengetahui pengaruh perbedaan umur terhadap pertumbuhan dan produksi stek $A$. gangetica.

\section{MATERI DAN METODE}

Penelitian ini dilakukan dari bulan Desember 2017 - April 2018 di Laboratorium Lapang Agrostologi, Fakultas Peternakan Institut Pertanian Bogor. Bahan yang digunakan pada penelitian ini adalah tanah, pupuk kandang, pupuk NPK, bibit $A$. gangetica. Alat yang digunakan pada penelitian ini adalah polybag, pita ukur/penggaris, timbangan, label, alat tulis, kamera.

Penanaman A. gangetica dilakukan dalam polybag kapasitas media $5 \mathrm{~kg}$. Media tanam yaitu terdiri dari tanah dicampur dengan pupuk dengan perbandingan 2:1 dan ditambahkan pula pupuk NPK sebanyak 50 $\mathrm{kg} / \mathrm{ha}$. Dilakukan penyiraman dua kali dalam sehari agar kebutuhan air tanaman dapat terpenuhi. Selama masa pertumbuhan tanaman A. gangetica dilakukan pengamatan dan pengukuran tinggi tanaman dan jumlah cabang pada setiap minggunya. A. gangetica dipanen pada umur 50, 70 dan 90 hari setelah tanam. Pada saat pemanenan parameter diukur yaitu tinggi saat panen, berat segar batang, jumlah stek dan diameter stek.

Rancangan percobaan yang digunakan untuk adalah rancangan acak lengkap (RAL) menurut Steel dan Torrie (1995) dengan 3 perlakuan dan 23 kali ulangan. Data yang diperoleh dianalisis sidik ragam 
(ANOVA) dengan software Ri386 3.3.2 dan dilakukan uji lanjut LSD jika ada perbedaan nyata. Hubungan antara variable pertumbuhan tanaman dengan produksi stek dianalisis dengan matriks korelasi Produk-Momen Pearson dengan observasi lengkap.

\section{HASIL DAN PEMBAHASAN}

\section{Pertumbuhan A.gangetica}

Pertumbuhan tanaman A. gangetica dapat dilihat dari hasil pengukuran tinggi tanaman setiap 7 hari selama masa pemeliharaan (Gambar 1). Pola pertambahan tinggi tanaman A. gangetica menunjukkan bentuk grafik sigmoid yang menunjukkan 3 fase pertumbuhan, yaitu: 1) fase lag di mana pertumbuhan relatif lambat dengan jumlah sel-sel yang membelah hanya sedikit (0-14 hari); 2) fase $\log$ /eksponensial dimana pertumbuhan mencapai maksimum, sel-sel aktif membelah dan mengalami elongasi (15-70 hari), dan 3) fase pertumbuhan lambat atau mengalami perubahan secara konstan (71-90 hari). Dalam pengamatan ini, sebagian besar tanaman A. gangetica masih terus tumbuh secara konstan dan belum mengalami kematian. Menurut Mendonça et al. (2012), fase pertumbuhan yang dialami oleh setiap tanaman bisa berbeda-beda karena perbedaan karakter tumbuh tanaman secara spesifik.

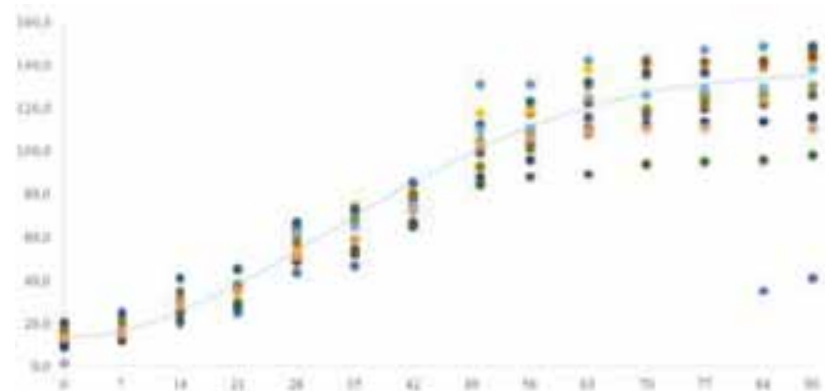

Gambar 1. Pola pertambahan tinggi tanaman A. gangetica selama 90 hari

Pola pertambahan tinggi tanaman pada Gambar 1 penting untuk menggambarkan kematangan atau tingkat kedewasaan tanaman dan panjang batang yang dapat digunakan untuk memproduksi stek $A$. gangetica. Pola khas pertumbuhan tanaman ini sangat berpengaruh pada daya adaptasi tanaman dalam memaksimalkan kerja daun sebagai pusat asimilasi dan suplai energi untuk pertumbuhan tanaman (da Silva et al., 2015). Kurva pertumbuhan menunjukkan pada pentingnya bagian awal pertumbuhan dan kecepatan tumbuh selama penanaman.

Umur tanaman A.gangetica berpengaruh pada tinggi dan berat batang segar yang dihasilkan tanaman (Tabel 1). Hasil analisis statistik menunjukkan bahwa pertambahan tinggi A.gangetica dalam umur antara umur 50 dan 70 HST tidak berbeda nyata namun
Tabel 1. Pengaruh umur tanaman A.gangetica terhadap tinggi, berat batang, jumlah ranting

\begin{tabular}{lccc}
\hline Parameter & 50 HST & 70 HST & 90 HST \\
\hline Tinggi $(\mathrm{cm})$ & $106,4 \pm 12,4 \mathrm{~B}$ & $97,7 \pm 8, \mathrm{oB}$ & $128,1 \pm 12,3 \mathrm{~A}$ \\
Berat batang segar $(\mathrm{g})$ & $124,1 \pm 12, \mathrm{ob}$ & $63,3 \pm 5,6 \mathrm{c}$ & $156,7 \pm 18,6 \mathrm{a}$ \\
Jumlah ranting primer & $2,6 \pm 1,1 \mathrm{~b}$ & $5,3 \pm 1,2 \mathrm{a}$ & $2,4 \pm 1,1 \mathrm{~b}$ \\
Jumlah ranting sekunder $18,7 \pm 3,7 \mathrm{~b}$ & $27,7 \pm 6,3 \mathrm{a}$ & $25,1 \pm 8,4 \mathrm{ab}$ \\
Jumlah ranting tersier & $15,8 \pm 4,7 \mathrm{~b}$ & $17,6 \pm 9,7 \mathrm{~b}$ & $39,9 \pm 15,1 \mathrm{a}$ \\
\hline
\end{tabular}

Keterangan: huruf kapital pada baris yang sama menunjukkan perbedaan nyata pada taraf $p>0,001$ huruf pada baris yang sama menunjukkan perbedaan nyata pada taraf $p>0,01$

pada umur 9o HST tinggi tanaman meningkat pesat

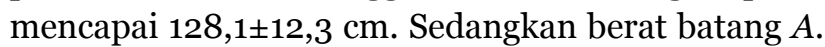
gangetica menunjukkan pola yang sedikit berbeda, di mana berat batang segar pada umur 70 HST lebih rendah dari A. gangetica umur 50 HST.

Pola yang berbeda tampak pada perkembangan jumlah ranting primer, sekunder dan tersier. Ranting primer adalah cabang yang tumbuh dari batang utama bibit $A$. gangetica, sedangkan ranting sekunder adalah cabang yang tumbuh dari ranting primer sedangkan ranting tersier tumbuh dari ranting sekunder. Ranting primer dan sekunder yang dihasilkan $A$. gangetica umur 70 HST mencapai 5,3 $\pm 1,2$ lebih tinggi daripada umur 50 dan 90 HST. Secara keseluruhan tampak bahwa jumlah ranting primer cenderung tetap sedangkan pertambahan ranting primer dan sekunder cenderung meningkat hingga sekitar umur 6o HST.

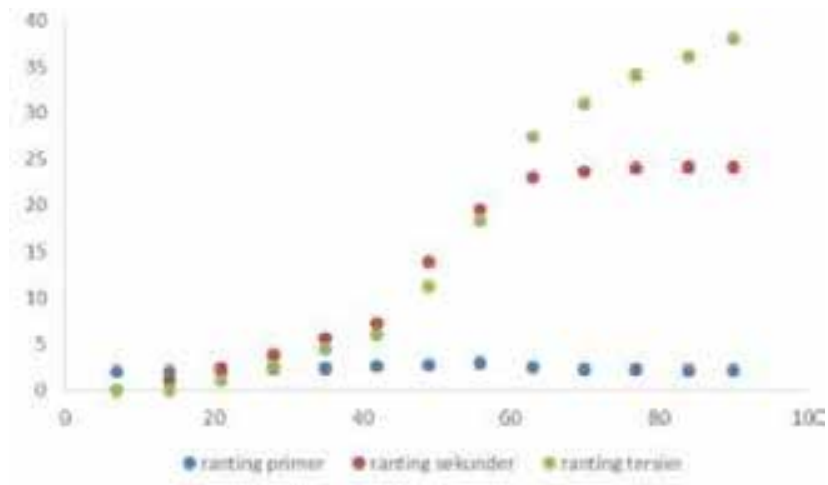

Gambar 2. Pola pertumbuhan ranting primer, sekunder, dan tersier

\section{Produksi Stek}

Jumlah stek yang dihasilkan pada umur 90 HST

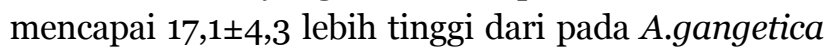
berumur 50 dan 70 HST. Namun pada diameter batang A.gangetica umur 50 HST lebih rendah dari pada umur 70 dan 90 HST tidak berbeda nyata, berkisar $4,3 \mathrm{~mm}$. Hal ini mengindikasikan bahwa kualitas stek yang dihasilkan A.gangetica berumur 70 dan 90 HST relatif sama karena diameter stek merupakan komponen penting untuk pertumbuhan individu baru, terutama tinggi tanaman dan jumlah tunas individu baru yang dihasilkan (Hutasoit et al., 2013). 
Tabel 2. Pengaruh umur tanaman A.gangetica terhadap jumlah dan diameter stek

\begin{tabular}{lccc}
\hline Parameter & 50 HST & 70 HST & 90 HST \\
\hline Jumlah stek & $6,3 \pm 1,8 \mathrm{C}$ & $8,5 \pm 3,1 \mathrm{~B}$ & $17,1 \pm 4,3 \mathrm{~A}$ \\
Diameter stek $(\mathrm{mm})$ & $3,6 \pm 0,5 \mathrm{~b}$ & $4,3 \pm 0,6 \mathrm{a}$ & $4,3 \pm 0,7 \mathrm{a}$ \\
\hline Keterangan: $\begin{array}{l}\text { huruf kapital pada baris yang sama menunjukkan perbedaan nyata } \\
\text { pada taraf } \mathrm{p}>0,001 \text { huruf pada baris yang sama menunjukkan } \\
\text { perbedaan nyata pada taraf } \mathrm{p}>0,01\end{array}$
\end{tabular}

Hubungan antara umur, tinggi, jumlah ranting dengan jumlah stek yang dihasilkan

Hubungan antara umur, tinggi, jumlah ranting primer, sekunder, tersier dengan jumlah stek yang dihasilkan dapat dilihat pada Tabel 3. Hubungan antara variabel berkisar antara kecil hingga erat. Umur tanaman memiliki korelasi negatif dengan pembentukan ranting primer $(-0,041)$ yang menunjukkan bahwa bertambahnya umur tanaman tidak terjadi penambahan jumlah ranting primer. Umur tanaman memiliki korelasi sedang dengan tinggi tanaman dan pembentukan ranting sekunder, dan korelasi yang erat dengan jumlah stek yang dihasilkan.

Tabel 3. Hasil analisis korelasi umur, tinggi, jumlah ranting primer, sekunder, tertier dan jumlah stek

\begin{tabular}{lcccccc}
\hline & & $\begin{array}{c}\text { Tinggi } \\
\text { tana- } \\
\text { man }\end{array}$ & $\begin{array}{c}\text { Ranting } \\
\text { primer }\end{array}$ & $\begin{array}{c}\text { Ranting } \\
\text { sekunder }\end{array}$ & $\begin{array}{c}\text { Ranting } \\
\text { tersier }\end{array}$ & $\begin{array}{c}\text { Jumlah } \\
\text { stek }\end{array}$ \\
\hline Umur & 1,000 & 0,428 & $-0,041$ & 0,359 & 0,651 & 0,785 \\
$\begin{array}{l}\text { Tinggi } \\
\text { tanaman }\end{array}$ & 0,428 & 1,000 & $-0,374$ & $-0,089$ & 0,312 & 0,483 \\
$\begin{array}{l}\text { Ranting } \\
\text { primer }\end{array}$ & $-0,041$ & $-0,373$ & 1,000 & 0,491 & $-0,248$ & $-0,211$ \\
$\begin{array}{l}\text { Ranting } \\
\text { sekunder }\end{array}$ & 0,359 & $-0,089$ & 0,491 & 1,000 & 0,334 & 0,111 \\
$\begin{array}{l}\text { Ranting } \\
\text { tersier }\end{array}$ & 0,651 & 0,311 & $-0,248$ & 0,334 & 1,000 & 0,528 \\
$\begin{array}{l}\text { Jumlah } \\
\text { stek }\end{array}$ & 0,785 & 0,483 & $-0,211$ & 0,111 & 0,528 & 1,000 \\
\hline
\end{tabular}

Jumlah stek memiliki korelasi positif dengan umur, tinggi tanaman, ranting sekunder dan ranting tersier. Korelasi jumlah stek yang dihasilkan dengan ranting primer bernilai negatif $(-0,211)$ hal ini karena jumlah ranting primer cenderung konstan sehingga dimungkinkan hubungan jumlah stek dengan ranting primer lebih terkait dengan dengan panjang ranting primer. Jumlah stek memiliki korelasi kecil dengan jumlah ranting sekunder dan korelasi sedang dengan jumlah ranting tersier. Hal ini berarti bahwa produksi stek secara umum banyak berasal dari ranting tersier yang terbentuk, terutama pada umur 9o HST.

\section{SIMPULAN}

Pertumbuhan tanaman A.gangetica hingga umur 90 hari membentuk pola sigmoid yang mencakup tiga fase pertumbuhan morfologi dan anatomi. Tanaman berumur 90 hari memiliki tinggi $(128,1 \pm 12,3 \mathrm{~cm})$ dan berat batang terbaik $(156,7 \pm 18,6 \mathrm{~cm})$ serta menghasilkan jumlah stek yang terbanyak $(17,1 \pm 4,25)$ dan diameter stek terbesar $(4,3 \pm 0,7 \mathrm{~mm})$. Produksi stek $A$. gangetica dihasilkan dari ranting sekunder dan tersier.

\section{UCAPAN TERIMA KASIH}

Menristekdikti atas pendanaan penelitian dengan skema PDUPT (Penelitian Dasar Unggulan Perguruan Tinggi) tahun anggaran 2018.

\section{DAFTAR PUSTAKA}

Clarizky A., E Yuliadi, dan Ardian. 2015. Berbagai pengaruh perlakuan pada stek batang ubikayu (Manihot esculenta Crantz) terhadap pertumbuhan ubi. Jurnal Kelitbangan. 02 (03): 96-107. Hutasoit R., A. Tarigan, S. P. Ginting. 2013. Pengaruh Diameter Stek Batang terhadap Pertumbuhan Bibit Pada Empat Spesies Tanaman Murbei (Morus sp.). Seminar Nasional Teknologi Peternakandan Veteriner. http:// lolit kambing. litbang. pertanian. go.id/ ind/ images/ prosiding/prosiding \%202.pdf

Kumalasari, N. R., L. Wahyuni, L. Abdullah. 2018. Germination of Asystasia gangetica seeds exposed to different source, color, size, storage duration and pre-germinative treatments. Proceeding of the $4^{\text {th }}$ Intenational Seminar on Animal Industry. Bogor (ID). p: 130-134.

Mendonça, E. G, L. V. Paiva, V. C. Stein, M. F. Pires, B. R. Santos, F. J. Pereira. 2012. Growth Curve and Development of the Internal Calli Structure of Eucalyptus camaldulensis Dehn. Braz.Arch. Biol. Technol. 55(6): 887-896.

Prusinkiewicz, P. 1998. Modeling of spatial structure and development of plants. Scientia Horticulturae. 74: 113-149.

Putra, R. I. 2018. Morfologi, Produksi Biomassa dan Kualitas Ara Sungsang (Asystasia gangetica (L.) T. Anderson) sebagai Hijauan Pakan di Beberapa Wilayah Jawa Barat dan Banten. [Skripsi]. Bogor (ID): Fakultas Peternakan IPB.

Rodrigues, C. S., D. N. Júnior, S. C. da Silva, M. C. T. da Silveira, B. M. L. Sousa, E. Detmann. 2011. Characterization of tropical forage grass development pattern through the morphogenetic and structural characteristics. R. Bras. Zootec. 40 (3): 527-534.

da Silva, S. C., A. F. Sbrissia, L. E. T. Pereira. 2015. Ecophysiology of $\mathrm{C}_{4}$ forage grassesUnderstanding plant growth for optimising their use and management. Agriculture. 5: 598-625. 